\title{
Effects of Varicocelectomy on Abnormal Semen Parameters in Patients with Clinically Palpable Varicocele
}

\author{
Morshed MS ${ }^{1}$, Alam AKMK ${ }^{2}$, Islam AKMA ${ }^{2}$, Zaman $\mathrm{SB}^{3}$, Alam $\mathrm{MS}^{4}$, Islam N \\ ${ }^{I}$ Department of Urology, Dhaka Medical College and Hospital, Bangladesh \\ ${ }^{2}$ Department of Urology, Bangabandhu Sheikh Mujib Medical University (BSMMU), Dhaka, Bangladesh \\ ${ }^{3}$ Maternal and Child Health Division, ICDDR,B, Dhaka, Bangladesh, \\ ${ }^{4}$ Department of Urology, Dhaka Medical College and Hospital, Bangladesh, \\ ${ }^{5}$ Department of Obstetrics and Gynaecology, Dhaka Medical College and Hospital, Bangladesh
}

e-mail:psuvo56@gmail.com

\begin{abstract}
Prevalence of varicocele is approximately $15.1 \%$ among the general population. Studies showed that surgical correction of clinically palpable varicocele could improve the semen parameters. However, there is scarce of study to demonstrate post-operative outcome of varicocelectomy among the patients with abnormal semen parameter. Therefore, this study tried to compare the microscopic changes in sperm concentration, sperm motility and sperm morphology before and after varicocelectomy. This quasi experimental study was done in Urology Department of Bangabandhu Sheikh Mujib Medical University (BSMMU), Dhaka, Bangladesh from November 2014 to April 2016. Forty five patients with clinically palpable varicocele were finally included in the study. Semen parameters of these patients were assessed according to the manual of the World Health Organization. Subinguinal varicocelectomy was performed in every case. Follow up was done three months and six months after surgery. Almost $60.0 \%$ of patients were from 25 to 35 years age group. Of them, $87.1 \%$ patients were presented with left-sided varicocele, and $80 \%$ were grade III. All the patients showed oligospermia on semen analysis, whereas the number of abnormal sperm motility and abnormal morphology was 39 and 9 respectively. After surgical correction of varicocele, mean improvement of sperm concentration, motility and morphology found in 35 patients $(77.7 \%), 31$ patients $(79.4 \%)$ and six patients $(66.6 \%)$ respectively. The improvement was statistically significant $(p<0.05)$. This study showed that surgical treatment could lead to the betterment of semen parameters in patients with clinically palpable varicocele, which will guide in deciding the management of varicocele patients presented with abnormal semen parameter. However, to recommend varicocelectomy as a most useful procedure in treating infertility cases; further longitudinal studies are recommended to establish the impact of varicocelectomy on fertility.
\end{abstract}

Keywords: Varicocele, Abnormal semen parameters, Varicocelectomy

\section{Introduction}

Varicocele is known to be an abnormal dilation and tortuosity of the internal spermatic veins within the pampiniform plexus of the spermatic cord. ${ }^{1}$ It is the most frequent abnormal physical finding in men who present for an infertility evaluation. $^{2}$ The prevalence of varicocele is approximately $15.1 \%$ in the general population, ranging from $19.0 \%$ to $41.0 \%$ in accounting the primary and $45.2 \%$ to $81.1 \%$ with secondary infertility $^{3}$. In a contemporary study of 7,035 military recruits fromsix European countries showed that the prevalence is $15.7 \%$. Among men with varicocele, only $1.1 \%$ had bilateral disease, and $0.2 \%$ had anisolated right-sided varicocele on physical examination ${ }^{4}$.It has been reported that only $20.2 \%$ of men with documented varicoceles usually suffer with the fertility problems. However, varicocele repair appears to have beneficial effects in men with impaired semen parameters and palpable varicoceles. ${ }^{5}$

There are several mechanisms which cause progressive deterioration and generalized impairment of sperm production. ${ }^{6}$ Varicocele has 
marked impact on semen parameters like abnormalities in sperm concentration, sperm motility, and morphology. ${ }^{7}$ Varicocele can progressively deteriorate the sperm production resulting in abnormal quality; ranging from oligospermia to complete azoospermia. ${ }^{8}$ However, varicocele is also known as the surgically correctable cause of male infertility, and it is a commonly performed surgical procedure. ${ }^{9}$ Significant improvement of some parameters occurs after surgical correction of clinically palpable varicocele. ${ }^{10}$ There are studies which showed that surgical correction of clinically palpable varicocele (varicocelectomy) could improve the semen parameters for some patients. ${ }^{11-13}$

However, there is scarce of study to demonstrate the postoperative outcome of varicocelectomy among the patients with abnormal semen parameter. So far, no study is yet done to see the efficacy of varicocelectomy among the patients with abnormal semen parameter in Bangladesh. Therefore, this study was tried to compare the microscopic changes in sperm concentration, sperm motility, and sperm morphology after varicocelectomy.

\section{Materials and Methods}

This study quasi experimental study was done in Urology Department of Bangabandhu Sheikh Mujib Medical University (BSMMU), Bangladesh from November 2014 to April 30, 2016.

Referring to the studies and using the formula below, the estimated sample size was $45.3,14$

$$
\frac{\left\{u \sqrt{[\pi(1-\pi)]}+v \sqrt{\left[\pi_{0}\left(1-\pi_{0}\right)\right]}\right\}^{2}}{\left(\pi-\pi_{0}\right)^{2}}
$$

Here, $\pi=0.758$

here,

$\pi_{0}=0.9$ (hypothesized value)

$\mathrm{u}=0.84$ (in $80 \%$ power)

$\mathrm{v}=1.96$ (in 5\% significant level)

All patients attended to Urology outpatient department of BSMMU from where patients with clinically palpable varicocele were selected initially for the study. Patients having age between 18 to 45 years; clinically palpable varicocele; with any abnormal semen parameter: sperm concentration, motility or morphology were included in the study. Patients with secondary and recurrent varicocele, any abnormality of testes, epididymis and vas deferens, history of orchitis, testicular trauma and inguinoscrotal surgery were the excluded from the study. Finally, data were collected from 45 patients, by two physicians. Collected data were checked and edited by the authors.

\section{Pre-operative and post-operative evaluation}

A detailed history was taken, and clinical examination was done for each patient to identify clinically palpable varicocele. The diagnosis of clinical varicocele was performed by physical examination and supported by Doppler ultrasound of testicular veins. Semen analysis was obtained by following standard semen collection technique: semen was obtained from married participants by masturbation after a 2-3days period of sexual abstinence. Those who were unmarried, semen was collected after confirmation that no masturbation within last 4872 hours. Semen analysis of all patients was done from the infertility laboratory of BSMMU. In this study, subinguinal varicocelectomy was performed under spinal anesthesia for every case. Follow-up was done on three months and sixmonths after surgery. For each follow-up, physical examination and semen analysis were performed.

\section{Definition of variables and measurements}

Clinical varicocele has been considered for the Grade II and Grade III varicocele in this study. It was considered the following definition according to World Health Organization's $5^{\text {th }}$ Manual of semen parameter: Normal sperm morphology as sperm morphology > $4 \%$ of normal form; Normal motility of sperm: the sum of progressive (a) and non-progressive (b) movement $\geq 40 \%$ or only progressive movement $\geq 32 \%$; and Oligospermia: sperm concentration $<15$ million $/ \mathrm{ml} .{ }^{15}$ Asthenoteratozoospermia was considered as the condition when there are abnormal sperm motility and morphology. Moreover, in case of abnormal sperm concentration, motility, and morphology, it has been considered as oligoasthenoteratozoospermia: Abnormal sperm concentration, motility, and morphology. ${ }^{16}$ Abnormal sperm motility, abnormal sperm morphology, and abnormal sperm concentration were defined asthenospermia, teratozoospermia, and oligoasthenospermia respectively. 
Written informed consent from each participant was obtained at the time of enrolment. Every participantwas explained about the aims and objectives of the study. This study was approved by the Research Review Committee of the Bangabandhu Sheikh Mujib Medical University, Dhaka, Bangladesh.

All the data were collected by face to face interview using a structured questionnaire by two medical doctors. Data extraction was done from medical records and laboratory investigation of patients. The data were analyzed with statistical software SPSS 20, and level of significance was assessed by paired t test considering $p$ value less than 0.05 .

There were some limitations of this study including short study period, the inclusion of both the married and unmarried male, and pregnancy was not considered as an outcome; other operative procedures were not compared. However, the study was done in a tertiary hospital by a qualified surgeon, and follow up protocol was maintained strictly. Semen analyses before and after surgery were done from a single laboratory, and the operative procedure was performed as day case surgery.

\section{Results}

Almost $60.1 \%$ of patients were from 25 to 35 years age group, and mean age was $28.3 \pm 6.0$ years (table I).

Table I. Age distribution of patients

\begin{tabular}{lcc}
\hline Age group & $\begin{array}{l}\text { Number of } \\
\text { patients }\end{array}$ & Percentage \\
\hline 18-25 years & 14 & $31.1 \%$ \\
26-35 years & 27 & $60.0 \%$ \\
$36-45$ years & 04 & $8.9 \%$ \\
\hline
\end{tabular}

Among 45 patients 39 had left side, and 6had abilateral varicocele. Among 39, 34 had grade III, and 5 had grade II varicocele (table II).

Table II. Distribution of patients according to side and grade of varicocele

\begin{tabular}{lclc}
\hline $\begin{array}{l}\text { Side of } \\
\text { varicocele }\end{array}$ & $\begin{array}{l}\text { Number of } \\
\text { patients } \\
\text { Left }\end{array}$ & $\begin{array}{l}\text { Grade of } \\
\text { varicocele } \\
\text { Right }\end{array}$ & $\begin{array}{l}\text { Percentage } \\
(\%)\end{array}$ \\
\hline $\begin{array}{l}\text { Isolated } \\
\text { left }\end{array}$ & 39 & $\begin{array}{l}\text { Gr. III } \\
(\mathrm{n}=34)\end{array}$ & $86.7 \%$ \\
& & $\begin{array}{l}\text { Gr. II } \\
(\mathrm{n}=05)\end{array}$ & 0 \\
$\begin{array}{l}\text { Isolated } \\
\text { right }\end{array}$ & 0 & & 0 \\
Bilateral & 06 & Gr.III Gr I & $13.3 \%$ \\
\hline
\end{tabular}

Those presented with bilateral varicocele had left-sided grade IIIand right sided grade I varicocele. All the patients had oligospermia on pre-operative semen analysis, whereas the number of abnormal sperm motility (asthenospermia) and abnormal morphology (teratozoospermia) was 39 and 09 , respectively. After further classification of the participants, nine patients were detected to have oligoasthenoteratozoospermia, 39 had oligoasthenozoospermia and nine had developed asthenoteratozoospermia (table III)

Table III. Distribution of patients by preoperative semen parameters

\begin{tabular}{lc}
\hline Sperm parameters & Number of patients \\
\hline Oligospermia & 45 \\
Asthenospermia & 39 \\
Teratozoospermia & 09 \\
Oligoasthenoteratozoospermia & 09 \\
Oligoasthenospermia & 39 \\
Asthenoteratozoospermia & 09 \\
\hline Sperm Concentration, Motility in patients & before and after \\
surgery &
\end{tabular}

In this study, ten patients had sperm concentration $<5$ million/ml, 22 had sperm concentration in between 6-10 million/ml, and 13 had between 11-14 million/ml before surgery. However, considering sperm concentration in patients after surgery $(n=45)$ in all groups, the mean sperm concentration improved after surgery and they were found statistically significant. During firstfollow-up mean improvement noticed in 29 patients and during secondfollow-up in 35 patients (table IV).

Concerning sperm motility in astheno spermic patients, between 6-10 million/ml and 11-14 million/ml group, the pre-operative sperm motility on semen analysis were almost same. However, the mean sperm motility improved after surgical correction in all groups, and it was statistically significant $(p<0.05)$. During firstfollow-upmean improvement was noticed among the 26 patients and during the secondfollow-up 31 patients were found to have improve sperm motility. 
Table IV. Sperm concentration and motility in patients before and after surgery

\begin{tabular}{|c|c|c|c|c|c|c|}
\hline $\begin{array}{c}\text { Sperm } \\
\text { Concent } \\
\text { ration } \\
\text { (million/ } \\
\text { ml) }\end{array}$ & $\begin{array}{c}\text { Numbe } \\
r \text { of } \\
\text { patien } \\
t\end{array}$ & $\begin{array}{c}\text { Pre- } \\
\text { opera } \\
\text { tive } \\
\text { Mean } \\
\pm \text { SD }\end{array}$ & $\begin{array}{l}1^{\text {st } F o l l ~} \\
\text { ow-up }\end{array}$ & $\begin{array}{c}\mathbf{p}^{*} \\
\text { Val } \\
\text { ue }\end{array}$ & $\begin{array}{c}2^{\text {nd }} \text { Fol } \\
\text { low- } \\
\text { up }\end{array}$ & $\begin{array}{c}\mathbf{p}^{* *} \\
\text { Value }\end{array}$ \\
\hline $\begin{array}{l}\text { All } \\
\text { patient }\end{array}$ & 45 & & & & & \\
\hline $\begin{array}{l}<5 \\
\text { million/ } \\
\mathrm{ml}\end{array}$ & 10 & $\begin{array}{l}2.4 \pm \\
2.5\end{array}$ & $\begin{array}{l}12.3 \pm \\
9.9\end{array}$ & $\begin{array}{l}< \\
0.01\end{array}$ & $\begin{array}{l}16.5 \pm \\
9.5\end{array}$ & $<0.01$ \\
\hline $\begin{array}{l}6-10 \\
\text { million/ } \\
\mathrm{ml}\end{array}$ & 22 & $\begin{array}{l}8.7 \pm \\
1.2\end{array}$ & $\begin{array}{l}25.3 \pm \\
12.2\end{array}$ & $\begin{array}{l}< \\
0.00 \\
1\end{array}$ & $\begin{array}{l}29.5 \pm \\
12.4\end{array}$ & $<0.001$ \\
\hline $\begin{array}{l}11-14 \\
\text { million/ } \\
\mathrm{ml}\end{array}$ & 13 & $\begin{array}{l}12.3 \pm \\
1.2\end{array}$ & $\begin{array}{l}33.5 \pm \\
9.1\end{array}$ & $\begin{array}{l}< \\
0.01\end{array}$ & $\begin{array}{l}37.4 \pm \\
8.7\end{array}$ & $<0.01$ \\
\hline $\begin{array}{l}\text { Astheno } \\
\text { spermic }\end{array}$ & 39 & & & & & \\
\hline $\begin{array}{l}<5 \\
\text { million/ } \\
\mathrm{ml}\end{array}$ & 07 & $\begin{array}{l}9.9 \pm \\
11.5\end{array}$ & $\begin{array}{l}27.5 \pm \\
11.6\end{array}$ & $\begin{array}{l}< \\
0.01\end{array}$ & $\begin{array}{l}35.9 \pm \\
10.1\end{array}$ & $<0.01$ \\
\hline $\begin{array}{l}6-10 \\
\text { million/ } \\
\mathrm{ml}\end{array}$ & 15 & $\begin{array}{l}24.5 \pm \\
7.4\end{array}$ & $\begin{array}{l}39.1 \pm \\
4.0\end{array}$ & $\begin{array}{l}< \\
0.01\end{array}$ & $\begin{array}{l}41.3 \pm \\
2.3\end{array}$ & $<0.01$ \\
\hline $\begin{array}{l}11-14 \\
\text { million/ } \\
\mathrm{ml}\end{array}$ & 17 & $\begin{array}{l}23.7 \pm \\
8.1\end{array}$ & $\begin{array}{l}40.0 \pm \\
2.5\end{array}$ & $\begin{array}{l}< \\
0.00 \\
1\end{array}$ & $\begin{array}{l}43.1 \pm \\
4.6\end{array}$ & $<0.001$ \\
\hline
\end{tabular}

Effect of varicocelectomy in patients with abnormal sperm morphology

The mean of the sperm morphology of the teratozoospermia patients $(n=9)$ before surgery was $1.0 \pm 1.2 \%$ and after varicocelectomy, it was $6.6 \pm 3.4 \%$ during $1^{\text {st }}$ follow up, and10.6 $\pm 6.2 \%$ during $2^{\text {nd }}$ follow up. Mean improvement noticed in 4 patients during $1^{\text {st }}$ follow-up and in 6 during subsequent follow-up. In this study, 9 patients had oligoasthenoteratozoospermia. After surgical correction, 5 patients had improvement of all the 3 parameters on $2^{\text {nd }}$ follow-up (one had asthenospermia at $1^{\text {st }}$ follow up that had corrected during $2^{\text {nd }}$ follow-up), 2 had asthenoteratozoosspermia and another two had oligoasthenospermia(table V).

Among the 39 oligoasthenospermic patients, 27 patients had improvement of both parameters (sperm concentration and sperm motility). However, five patients had persistent oligoasthenospermia, four patients had improvement of sperm concentration, and three had improvement of sperm motility. Five patients had improvement of both parameters after surgery among the asthenotertozoospermic patients $(n=9)$.

Table V. Characteristics of Sperm for the patients before and after the surgery

\begin{tabular}{|c|c|c|c|c|c|}
\hline $\begin{array}{l}\text { Semen } \\
\text { Parameter } \\
\text { (Sperm } \\
\text { Concentrat } \\
\text { ion) }\end{array}$ & $\begin{array}{l}\text { Pre- } \\
\text { operati } \\
\text { ve } \\
\text { Mean } \\
\pm \text { SD }\end{array}$ & $\begin{array}{l}\text { stFoll }^{\text {st }} \\
\text { ow-up }\end{array}$ & $\begin{array}{l}p^{*} \\
\text { Valu } \\
\text { e }\end{array}$ & $\begin{array}{l}2^{\text {nd }} \text { Foll } \\
\text { ow-up }\end{array}$ & $p^{* * *}$ Value \\
\hline \multicolumn{6}{|c|}{ Teratozoospermic $(n=9)$} \\
\hline $\begin{array}{l}\text { Sperm } \\
\text { morphology } \\
(\%)\end{array}$ & $\begin{array}{l}1.0 \pm \\
1.2\end{array}$ & $\begin{array}{l}6.6 \pm \\
3.4\end{array}$ & $\begin{array}{l}< \\
0.00 \\
1\end{array}$ & $\begin{array}{l}10.6 \pm \\
6.2\end{array}$ & $<0.01$ \\
\hline \multicolumn{6}{|c|}{ Oligoasthenoteratozoospermic $(n=9)$} \\
\hline $\begin{array}{l}\text { Sperm } \\
\text { conc.(mill/ } \\
\text { ml) }\end{array}$ & $\begin{array}{l}4.8 \pm \\
5.9\end{array}$ & $\begin{array}{l}14.6 \pm \\
11.9\end{array}$ & $\begin{array}{l}< \\
0.01\end{array}$ & $\begin{array}{l}19.2 \pm \\
11.4\end{array}$ & $<0.001$ \\
\hline $\begin{array}{l}\text { Sperm } \\
\text { motility }(\%)\end{array}$ & $\begin{array}{l}13.6 \pm \\
14.5\end{array}$ & $\begin{array}{l}31.5 \pm \\
11.9\end{array}$ & $\begin{array}{l}< \\
0.00 \\
1\end{array}$ & $\begin{array}{l}38.7 \pm \\
6.4\end{array}$ & $<0.001$ \\
\hline $\begin{array}{l}\text { Sperm } \\
\text { morphology } \\
(\%) \\
\text { Oligoasthen }\end{array}$ & $\begin{array}{l}1.0 \pm \\
1.2 \\
\text { permic }(\mathrm{I}\end{array}$ & $\begin{array}{l}5.6 \pm \\
3.8 \\
\text { 20) }\end{array}$ & $\begin{array}{l}< \\
0.05\end{array}$ & $\begin{array}{l}8.5 \pm \\
6.6\end{array}$ & $<0.05$ \\
\hline $\begin{array}{l}\text { Sperm } \\
\text { conc.(mill/ } \\
\mathrm{ml})\end{array}$ & $\begin{array}{l}8.2 \pm \\
4.0\end{array}$ & $\begin{array}{l}24.3 \pm \\
15.0\end{array}$ & $\begin{array}{l}< \\
0.00 \\
1\end{array}$ & $\begin{array}{l}31.6 \pm \\
14.7\end{array}$ & $<0.001$ \\
\hline $\begin{array}{l}\text { Sperm } \\
\text { motility }(\%)\end{array}$ & $\begin{array}{l}25.2 \\
\pm 11.9\end{array}$ & $\begin{array}{l}36.2 \pm \\
11.5\end{array}$ & $\begin{array}{l}< \\
0.00 \\
1\end{array}$ & $\begin{array}{l}41.2 \pm \\
8.1\end{array}$ & $<0.001$ \\
\hline \multicolumn{6}{|c|}{ Asthenoteratozoospermic $(n=9)$} \\
\hline $\begin{array}{l}\text { Sperm } \\
\text { motility }(\%)\end{array}$ & $\begin{array}{l}11.6 \pm \\
14.5\end{array}$ & $\begin{array}{l}31.5 \pm \\
11.9\end{array}$ & $\begin{array}{l}< \\
0.00 \\
1\end{array}$ & $\begin{array}{l}39.7 \pm \\
11.8\end{array}$ & $<0.001$ \\
\hline $\begin{array}{l}\text { Sperm } \\
\text { morphology } \\
(\%)\end{array}$ & $\begin{array}{l}1.0 \pm \\
1.2\end{array}$ & $\begin{array}{l}6.6 \pm \\
3.4\end{array}$ & $\begin{array}{l}< \\
0.00 \\
1\end{array}$ & $\begin{array}{l}10.6 \pm \\
6.2\end{array}$ & $<0.01$ \\
\hline
\end{tabular}

P*: Statistically significant during $1^{\text {st }}$ follow-up $\mathrm{P} * *$ : Statistically significant during $2^{\text {nd }}$ follow-up

\section{Discussion}

The effects of varicocele on semen parameters caused by several mechanisms and varicocelectomy seem to reverse this conditions and thereby improvement of semen parameters occur. ${ }^{17}$ This study revealed that there was a marked improvement of semen parameter after varicocelectomy and this finding corresponds to a previous article. ${ }^{18}$ Ingrid Schauer et al. focused in their meta-analysis on the last 20 years, a total of 94 articles have reported that sub-inguinal varicocelectomy can lead to an improvement in sperm count. ${ }^{4}$ Khan et al. found that the mean improvement of sperm concentration 8.4 million $/ \mathrm{ml} .{ }^{19}$ In the present study, the distribution of mean age was 28.3 years which was almost equal to the average age of another study. ${ }^{3}$ 
However, participants this study wereolder than a previous study finding where the average age of respondents was 24.5 years. ${ }^{20}$

In the present study, those who had sperm concentration 5 million $/ \mathrm{ml}$, the post-operative mean sperm concentration was increased to 12.3 million/ml. Among 6-10 million/ml and 11-14 million/ml group, the postoperative mean sperm concentration was $25.36 \mathrm{million} / \mathrm{ml}$ and 33.5 million/ml respectively. This study supports the previous communication, where Abdel-Meguid et al got a mean improvement of sperm concentration 14.1 million $/ \mathrm{ml}$ as well ${ }^{9}$. Cayan et al. found preoperative mean motile sperm $26.2 \%$, and it was improved to $34.2 \%$ after subinguinal varicocelectomy. ${ }^{6}$

Hsieh et al in their study found motile sperm concentration increased from $31.8 \%$ to $47.5 \%$ in the study sample group. ${ }^{21}$ Zini et al showed $10.3 \%$ mean improvement of sperm motility followed by subinguinal varicocelectomy. ${ }^{22}$ In this study, it was found that sperm motility was significantly increased after the varicocelectomy which was almost similar to a finding where Orhan et al. revealed 5\% mean improvement of sperm motility. ${ }^{23}$ Murat Çakan et al found improvement of normal morphology after surgery and during the follow-up. ${ }^{24}$ Barbalis et al. also found improved semen morphology after varicocelectomy. ${ }^{25}$ The present study showed that 9 among 45 patients had abnormal sperm morphology and their preoperative mean semen morphology was $1.0 \pm 1.2 \%$. After surgical correction of avaricocele, semen analysis showed improvement of sperm morphology that was $6.6 \pm$ $3.4 \%$ during $1^{\text {st }}$ follow up and $10.6 \pm 6.2 \%$ during the next follow up. However, in this study result does not support a previous finding where there was no significant improvement of sperm morphology following varicocelectomy. ${ }^{26}$ Regarding the post-operative complications, $4.4 \%$ of patients developed recurrence of varicocele, and $4.5 \%$ patients developed secondary hydrocele as acomplication and these findings were almost similar to a previous study. ${ }^{27}$

A study conducted with Iranian population in 2015, found that sperm concentration and sperm count was increased after surgery over the six months period. ${ }^{28}$ However, the study findings were not statistically significant. In this study, we found that improvement of sperm concentration was marked with statistical significance. The result of this study was found similar to a study conducted in Tamil Nadu, India from the period 2010 to 2013, which also showed a significant increase of sperm concentration, average sperm motility, and morphology of sperm postoperatively. ${ }^{29}$ However, Bakri et al conducted a study in Canada from 2002 to 2010 which did not found significant improvement in sperm concentration, sperm motility, and sperm morphology after performing surgery. ${ }^{30}$ However, in this study, it was found marked improvement of sperm concentration. The findings of the sperm morphology of that study were dissimilar with the finding of this study.

From above discussion, it was found that there was marked improvement of semen parameters after varicocelectomy. Therefore, this study will be helpful for deciding the management of patients with clinically palpable varicocele who are with abnormal semen parameter. It can be a low-cost intervention to prevent male infertility if adequately evaluated. Moreover, it would be cost effective in the sense that pregnancy can be possible by natural means.

\section{Conclusion}

Findings of this study will be helpful for the surgeons for taking decision in treating patients presented with clinically palpable varicocele with abnormal semen parameter. However, to recommend varicocelectomy as a useful procedure for treating sterility cases; further longitudinal studies are required to establish the impact of varicocelectomy with fertility. 


\section{Acknowledgements}

We would like to acknowledge the support of the respondents for their support and cooperation. We also like to thank Bangladesh Medical Research Council (BMRC)for funding this study.

\section{Conflict of Interests}

The authors declare that there was no conflict of interests in this study.

\section{References}

1. Kiraç M, Deniz N, Biri H. The effect of microsurgical varicocelectomy on semen parameters in men with non-obstructive azoospermia. Curr Urol. 2012;6136-40.

2. Kamischke A, Nieschlag E. Varicocele treatment in the light of evidence-based andrology. Human reproduction update. 2001;7:65-9.

3. Kibar Y, Seckin B, Erduran D. The effects of subinguinal varicocelectomy on Kruger morphology and semen parameters. The $\mathrm{J}$ of Urol. 2002;168:1071-4.

4. Damsgaard J, Joensen UN, Carlsen E, Erenpreiss J, Blomberg Jensen M, Matulevicius V, et al. Varicocele is associated with impaired semen quality and reproductive hormone levels: a study of 7035 healthy young men from six European countries. Eur Urol 2016;70: 1019-29.

5. Chiba K, Fujisawa M, Clinical Outcomes of Varicocele Repair in Infertile Men: A Review, World J Mens Health. 2016; 34: 101-109

6. Cayan S, Shavakhabov S, Kadioğlu A. Treatment of Palpable Varicocele in Infertile Men: A Metaanalysis to Define the Best Technique. J of Andrology. 2009;30:33-40.

7. Naftulin BN, Samuels SJ, Hellstrom WJ, Lewis EL, Overstreet JW. Semen quality in varicocele patients is characterized by tapered sperm cells. Fertility and sterility. 1991;56:149-51.

8. Gorelick JI, Goldstein M. Loss of fertility in men with varicocele. Fertility and sterility. 1993;59: 613-16.

9. Abdel-Maguid A-F, Othman I. Microsurgical and nonmagnifiedsubinguinal varicocelectomy for infertile men: a comparative study. Fertility and sterility. 2010;94:2600-3.

10. Said S, Aribarg A, Virutamsen P, Chutivongse S, Koetsawang S, Meherjee P, Kumar T, Cuadros A, Shearman R, Conway A. The influence of varicocele on parameters of fertility in a large group of men presenting to infertility clinics. Int $\mathbf{J}$ of Gynecology \& Obstetrics. 1993;40:274

11. Okuyama A, Fujisue H, Matsui T, Koh E, Kondoh N, Takeyama M, Nakamura M, Namiki M, Fujioka H. Preoperative parameters related to the improvement of semen characteristics after surgical repair of varicocele in subfertile men. Eur Urol. 1987;14:442-6.

12. Steckel J, Dicker A, Goldstein M. Relationship between varicocele size and response to varicocelectomy. The J of Urol. 1993;149:769-71.

13. Takahara M, Ichikawa T, Shiseki Y, Nakamura T, Shimazaki J. Relationship between grade of varicocele and the response to varicocelectomy. Int J of Urol. 1996;3:282-5.

14. Kirkwood B, Sterne J. Essential medical statistics, Blackwell Publishing Ltd. London; 2003.

15. World Health Organization. WHO. Laboratory manual for the Examination and processing of human semen: 5th Edition. Geneva: WHO;2010.

16. Konar H. DC Dutta's textbook of gynecology: JP Medical Ltd; 2016. Delhi, India.

17. Fujisawa M, Yoshida S, Kojima K, Kamidono S. Biochemical changes in testicular varicocele. Archives of Andrology. 1989;22:149-59.

18. Matkov TG, Zenni M, Sandlow J, Levine LA. Preoperative semen analysis as a predictor of seminal improvement following varicocelectomy. Fertility and sterility. 2001;75:63-8.

19. Khan M, Khan S, Pervez A, Nawaz H, Ahmed S, Tareen S. Evaluation of low ligation and high ligation procedures of varicocele. $\mathrm{J}$ of the $\mathrm{Col}$ of Physicians and Surgeons-Pakistan. 2003;13280-3.

20. Cakiroglu B, Sinanoglu O, Gozukucuk R. The effect of varicocelectomy on sperm parameters in subfertile men with clinical varicoceles who have asthenozoospermia or teratozoospermia with normal sperm density. ISRN Urol. 2013;2013.

21. Hsieh M-L, Chang P-L, Huang S-T, Wang T-M, Tsui K-H. Loupe-assisted high inguinal varicocelectomy for sub-fertile men with varicoceles. Chang Gung Medical Journal. 2003;26:479-84.

22. Zini A, Buckspan M, Jamal M, Jarvi K. Effect of varicocelectomy on the abnormal retention of residual cytoplasm by human spermatozoa. Hum Reproduction. 1999;14:1791-3.

23. Orhan I, Onur R, Semerciöz A, Firdolas F, Ardicoglu A, Köksal I. Comparison of two different 
microsurgical methods in the treatment of varicocele. Archives of Andrology. 2005;51:213-20.

24. Çakan M, Bakirtas H, Aldemir M, Demirel F, Altug U. Results of varicocelectomy in patients with isolated teratozoospermia. Urolinternationalis. 2008;80:172-6.

25. Barbalias GA, Liatsikos EN, Nikiforidis G, Siablis D. Treatment of varicocele for male infertility: a comparative study evaluating currently used approaches. Eur Urol. 1998;34:393-8.

26. Cakiroglu B, Sinanoglu O, Gozukucuk R. The effect of varicocelectomy on sperm parameters in Subfertile men with clinical Varicoceles who have asthenozoospermia or teratozoospermia with normal sperm density.ISRN Urol; 2013:1-3.

27. Cayan S, Shavakhabov S, Kadioglu A. Treatment of palpable Varicocele in infertile men: A meta- analysis to define the best technique. $\mathrm{J}$ of Andrology.2008; 30:33-40.

28. Sofimajidpour H, Ghaderi E, Ganji O. Comparison of the Effects of Varicocelectomy and Oral Lcarnitine on Sperm Parameters in Infertile Men with Varicocele. $\mathrm{J}$ of clinical and diagnostic research. 2016;10: PC07.

29. Kumar R, Sekar H, Krishnamoorthy S, Kumaresan N, Ramanan V. Analysis of Outcomes of Surgical Treatment for Varicocele in Primary Infertility Based on Seminal Parameters and Pregnancy Rate. Int J of Scientific Study. 2016;4:205-10.

30. Al Bakri A, Lo K, Grober E, Cassidy D, Cardoso JP, Jarvi K. Time for improvement in semen parameters after varicocelectomy. The J of Urol. 2012;187: 227-31. 